\title{
Capitalism and Second Slavery in Texas
}

Resenha de: TORGET, Andrew. Seeds of Empire: Cotton, Slavery, and the Transformation of the Texas Borderlands, 1800-1850. The University of North Carolina Press, 2015. 368 pp.

Ian Beamish*

University of Louisiana at Lafayette

Lafayette - Louisiana - United States of America

Three enslaved people - Richard, Tivi, and Marian - fled enslavement in Louisiana in 1819, seeking relief from the brutality of slavery in the United States in the northern borderlands of New Spain. At this time, the Mexican province of Tejas was home to a small population

* Assistant Professor of History of 19th Century US and History of Slavery in the University of Louisiana. E-mail: ian.beamish@louisiana.edu. 
of ethnic Mexicans, known as Tejanos, along with a larger indigenous population, including the powerful Comanche. Less than thirty years later, this area would be the state of Texas within the United States and home to the fastest-growing enslaved population in the slaveholding republic. In his meticulously-researched book, Andrew Torget follows the emergence of an Anglo-Texan society, nation, and, eventually, state. The book takes a firmly political and economic approach to history, which makes for a propulsive and clear narrative, but Richard, Tivi, and Marian aside, keeps that narrative largely the preserve of economically and politically powerful individuals and groups - legislators, empresarios, generals, and merchants. Torget masterfully integrates an intricate explanation of the politics of New Spain and Mexico with a more familiar narrative of the expansion of the United States cotton frontier into Texas. The advancing cotton frontier, however, appears mostly in the form of increasing numbers of cotton bales leaving Texas and the growth of migration of enslavers to the region, bringing with them enslaved people. Seeds of Empire thus occupies an interesting place, both linked to recent scholarship on the connections between slavery and capitalism in the nineteenth-century United States and circum-Caribbean world, like Walter Johnson's River of Dark Dreams, but also employing different methods and narrative strategies than much of that scholarship.

Seeds of Empire tells the history of the Texas borderlands in three sections, beginning with an introductory chapter on the region "on the eve of Mexican independence," continuing to a second part on the tension between the extension of the United States' cotton frontier into Mexico and increasing Mexican antipathy toward slavery in Mexico, and concluding with a section on independent Texas' attempts to create a successful proslavery cotton republic. It is in discussing the debates surrounding slavery in northern Mexico that Seeds of Empire makes its greatest contribution. Torget lays out an important and, in the historiography of Texas, largely untold narrative of the debates between proslavery Americans and Tejanos and antislavery political forces in Mexico. This section of the book transports readers to deba- 
tes in Saltillo and shows how important Mexican resistance to slavery would be for Anglo-Texans and enslaved people in Texas.

For Torget, there are three main factors that shape the period of the 1830s and 1840s when Texas seceded from Mexico and pushed to join the United States. He often glosses these three factors as "cotton, slavery and empire," but his fuller description of each factor is more revealing of the approach of the study. (6) Cotton is really the "rise of the global cotton economy," slavery is the "battles over slavery that followed," and empire is "the struggles of competing governments to control the territory" of Texas. (5-6) The brief terms suggest a clear connection to ideas scholars have recently termed "The New History of Capitalism" and "The Second Slavery," both of which emphasize economic shifts in plantation commodity production under slavery, an increasingly industrial approach to enslavement, and the expansion of plantation complexes to new territory. This scholarship, at its best, connects large shifts in economics, politics, and society to the lived experience of enslaved people. For example, in his River of Dark Dreams, Walter Johnson connects his discussion of the cotton economy to the daily lives of enslaved cotton pickers in Mississippi by tracing the journey of cotton from seed to boll to lint to bale on a Liverpool wharf. (Johnson, 246-279) While both Johnson and Torget use cotton as a way into the world of the Second Slavery, Torget chooses different individual human actors to focus on - largely politicians, empresarios, and powerful cotton planters. While this allows Seeds of Empire an admirably comprehensible and tight narrative of complex and oft-ignored political developments in northern Mexico and, later, Texas, it also means that enslaved people appear largely as subjects of debate, rather than agents of historical change. This is reflected in Torget's insistence that the aspect of slavery most shaping Texas is national and international debates in Mexico, the United States, and Europe over the future of slavery. This is a result of the political approach the book takes to explaining this period of the history of Texas, but it is still a missed opportunity. Adam Rothman, in writing a history of the advancing cotton frontier that Torget foregrounds, writes a narrative with a central role for politics and warfare, but also foregrounds the 
active role enslaved people played in shaping the cotton frontier with, for example, the German Coast Uprising.

Torget's key intervention - that the history of the Texas borderlands can only be understood in terms of the advancing United States cotton frontier - fits naturally into recent scholarship emphasizing capitalism and the Second Slavery, yet Seeds of Empire stands, in terms of its narrative approach, historical actors, and political and economic focus, in stark contrast to much of this work. Historians of the Second Slavery and the New History of Capitalism have largely sought to integrate the testimony of enslaved people, understand historical change as deeply influenced by the actions of enslaved people, and play down the influence of British abolitionism on the daily actions of enslavers in the United States. Torget convincingly argues that Mexican and British abolitionism was central to the history of the Texas borderlands, but is unable to reckon with the ways enslaved peoples actions shaped these borderlands. The book could have offered a fuller explanation of the failure of the Texan proslavery republic by integrating an approach similar to that of Stephanie McCurry's Confederate Reckoning, which combined an analysis of high politics with an emphasis on political history operating at all levels - showing that, in her case, the Confederacy was crumbling from within outside of its diplomatic and military defeats.

Torget's book presents an admirably clear and engaging narrative of the competing influences on the borderlands of northern Mexico and the southern United States. Seeds of Empire makes a significant contribution to existing scholarship on the southern United States and northern Mexico by showing how important the antislavery politics of New Spain and Mexico were to the expansion of cotton slavery in the Texan borderlands. While retaining the common emphasis on the importance of the United States cotton and slavery complex, empresarios, and the Comanche in shaping American immigration, the growth of slavery in the borderlands, and the eventual secession of Texas from Mexico, Torget forcefully demonstrates that it is nearly impossible to fully understand this process without a fuller understanding of the politics of Mexico that conditioned the actions of empresarios and free migrants from the United States. In many ways, the narrative 
shows that it was primarily determined Mexican resistance to slavery in the province of Tejas that prevented enslavers from the United States from migrating in large numbers before the secession of Texas, then the abolitionist politics of Great Britain and threat of Mexican military force that slowed this same migration before the United States annexed the Texan republic. Seeds of Empire is key reading for scholars interested in the history of Texas, the Second Slavery, and the history of the expansion of the United States. Historians of cotton slavery in the United States have recently emphasize the centrality of expansion into Texas to late-stage slavery in South and Torget provides an important step toward exploring and explaining that expansion.

Recebido: 07/08/2017 - Aprovado: 17/09/2017 